\title{
"Barbarian Ships Sail Freely about the Seas": Qing Reactions to the British Suppression of Piracy in South China, 1841-1856
}

\author{
C. Nathan Kwan \\ PhD Candidate, University of Hong Kong and King's College London \\ chingyin.kwan@gmail.com
}

\begin{abstract}
Chinese piracy presented numerous problems for the Qing and British empires in Chinese waters, but cooperation against pirates was rare before 1842 . The colonization of Hong Kong and other treaty arrangements after the Opium War enabled the British to take more vigorous action against Chinese pirates. Although such actions impinged on China's maritime sovereignty and jurisdiction, Qing officials quickly recognized the efficacy of British naval forces in suppressing piracy. Hong Kong and Kowloon developed a system of cooperation for the suppression of piracy. This system was replicated elsewhere along the coast of Guangdong and beyond. By receiving captured pirates from the Royal Navy, Qing officials effectively used an important tool of British imperialism as a means of enforcing and extending their own authority. At the same time, cooperation became a means for the Qing to engage with emerging international law.
\end{abstract}

\section{Keywords}

piracy - Sino-British relations - Hong Kong - Qing China - international law - Royal Navy

Piracy has been a problem along the China coast since ancient times and became particularly problematic on the coast of Guangdong from the late eighteenth century onwards. In addition to undermining Qing authority and the stability of one of the wealthiest, most populous regions in China, it also threatened maritime trade, the raison d'être for the Western presence in China 
(Antony 2016, 16-20). Piracy thus became a common nuisance that united the causes of the Qing Empire and the increasingly restless foreigners trading at Canton (Guangzhou 廣州). Chinese law, which prohibited foreign warships from sailing into the Canton River, and the European law of nations, which conceded that states had sovereignty over their territorial waters, prevented effective cooperation between Qing and foreign navies in suppressing piracy (Rubin 1988, 30; Morse 1910, 97). The situation changed with the colonization of Hong Kong and the establishment of a British imperial presence on the coast of China. British attempts to protect colonial waters and maritime trade often encroached on Qing maritime sovereignty (Chappell 2018, 475). Unable to resist the steamships and men-of-war of the most powerful navy in the world, Qing officials found the Royal Navy's actions against pirates in line with their own interests. Cooperation with British efforts to suppress piracy in effect allowed Qing officials to co-opt the Royal Navy into their own administration. In the process, the Qing engaged with an ascendant, European-dictated international law.

The earliest Europeans to arrive in China by sea came as merchants, but they often supplemented their commercial activities with outright piracy. Portugal, the first European maritime power to encounter China, encouraged piracy as an auxiliary to trade. The Dutch and British followed this example (Antony 2003, 27 and 34). By the end of the eighteenth century, however, most British ships going to China went for trade rather than piracy. The threat from rival navies, particularly that of the French, and from Chinese pirates meant the East India Company's (EIC) ships often required protection from the Royal Navy, which increased its presence in the seas around Canton, the sole port open to European trade since 1757 (Morse 1926 vol. II, 290 and 422-424; Van Dyke 2007, 16).

One of the earliest encounters between a Royal Navy warship and alleged Chinese pirates occurred on the night of 11 February 180o. Between 11 p.m. and midnight, a Chinese sampan approached HMs Providence and did not respond when hailed. Suspecting that the crew of the sampan intended to cut the Providence's anchor cable, the officer on duty fired at them with his musket. ${ }^{1}$ In doing so, he injured a crewmember named Jiang Yayou 蔣亞有. The British

1 Entry for 12 February 1800, IOR/G/12/128, $30-31$. 
captured the sampan, but Liu Yashi 劉亞定, another member of the crew, resisted arrest, fell overboard, and was not heard of again. ${ }^{2}$

Captain John Dilkes, the senior naval officer in China, took responsibility for the affair. Dilkes considered the action by the officer of the Providence a matter of "wounding the Thief." ${ }^{3}$ Though Dilkes never explicitly accused the crew of the sampan of piracy, he believed that

the laws of all civilized Countries on this head ... were nearly similar and he had no doubt but the persons who had made such an attempt on H.M. Vessel would be brought to Punishment as he could himself finding any excuse for withholding any one who had offended against the laws of this Country. ${ }^{4}$

Dilkes seemed to invoke the doctrine of universal competence in jurisdiction over pirates in expecting the Chinese to punish the piracy committed against H Ms Providence. ${ }^{5}$ When he and members of the Providence's crew were brought before a tribunal in Canton, he attempted to turn it into a prosecution of Chinese pirates. ${ }^{6}$ Qing officials acknowledged that the officer of the Providence "mistook a boat for a pirate." ${ }^{7}$ Governor-General Jiqing 吉慶 absolved the officer of the Providence, but "requested that all Europeans might be forbidden to fire with Ball at Boats that approached the Ships with however suspicious a design." Instead, Qing officials allowed British ships to "apprehend the Crew and detain them on board for a subsequent examination by the [Chinese] Officers of Justice." 8 After the Providence's engagement with an allegedly piratical sampan, the Qing conceded that the Royal Navy could take some actions against pirates but still claimed jurisdiction over those captured by the British.

As the problem of piracy off the southeast coast of China worsened, the Qing tacitly lifted restrictions on British actions against Chinese pirates. Two years after the Providence affair, merchants in Canton requested that the British keep armed ships in nearby waters for protection. In 1804, Qing officials turned to the Portuguese for assistance in suppressing piracy. The latter purchased the

2 Edict from the Haiguan, Jiaqing (JQ) reign, 5th year/1st month/27th day (20 February 180o), FO 233/189, 38-39.

3 "Dilkes to the Select Committee," 22 February 180o, IOR/G/128, 69.

4 Entry for 24 February 1800, IOR/G/128, 73 .

5 The doctrine of universal competence stipulated that pirates, as hostes humani generis (the enemies of all mankind), could be tried in any tribunal (Rubin 1988, 94; Benton 2011, 225).

6 Staunton to the Select Committee, 13 March 1800 , IOR/G/12/128, 123-125.

7 Edict from the Viceroy, Governor, and Hoppo, JQ 5/2/8 (3 March 1800), FO 233/189, 40.

8 Entry for 22 March 180o, IOR/G/12/128, 139; also see Chen 2016, 79-81. 
British ship Nancy, which accompanied Qing war junks on expeditions against pirates (Morse 1926 vol. II, 396 and 422). The Nancy succeeded in capturing twenty-nine pirates the following year and handed them over to Qing officials in Canton. After a trial, ten of the prisoners were beheaded outside the gates of Canton (Morse 1926 vol. III, 8). This model of cooperation would be repeated with the British after the colonization of Hong Kong. As the problem of piracy continued largely unabated, local Qing officials began seeking British assistance against piracy, sometimes in violation of the orders of their superiors.

On 10 September 1809, the magistrate of Xiangshan 香山 district sent a subordinate to request the assistance of H Ms Dedeigneuse, which would be given special permission to sail up the Canton River despite a ban on foreign warships in Chinese waters (Morse 1926 vol. III, 113-117). ${ }^{9}$ The following month, piracy had become so problematic that the governor of Guangdong 廣東 province himself approached the British for assistance, meeting with Captain Francis Austen of the Royal Navy to discuss cooperation. ${ }^{10}$ Austen, however, claimed he would need a commission from the governor-general before taking action against Qing subjects who had not attacked him. Austen insisted "that if HM ships were to be employed he must have liberty to place them wherever he thought proper either within or without the river" and demanded a meeting with the governor-general. ${ }^{11}$ Perhaps balking at this potential violation of Qing maritime sovereignty, Governor-General Bailing 百齡 ultimately refused to meet with Austen and turned to the Portuguese instead (Morse 1926 vol. III, 121-122). ${ }^{12}$

Qing officials' opinions of the British varied. In the wake of the British attempt to occupy Macao in 1808, officials like the governor-general were understandably reluctant to accept a British naval presence in China (Wakeman 2004, 27-34). Others, like the governor of Guangdong and the magistrate of Xiangshan, acknowledged the potential efficacy of British assistance in suppressing piracy. Qing refusal to allow the British to attack Chinese subjects, however, prevented the Royal Navy from cooperating with the Qing against pirates. The situation changed with the colonization of Hong Kong in the aftermath of the First Opium War (1839-1842). After 1841, the British could bypass the need for commissions to attack Chinese pirates and take actions in the

Entry for 10 September 1809. IOR/G/12/167, 187. Royal Navy convoy ships were not allowed to sail past the Bogue (Humen) into the Pearl River Delta. However, they were permitted to anchor just outside. See Edict by the Governor-General, JQ 10/intercalary 6/21 (17 July 1805), FO 233/189, 146.

10 Francis Austen was the elder brother of the famous novelist Jane Austen.

11 Entry for 30 October $1809, \mathrm{IOR} / \mathrm{G} / 12 / 168,56$.

12 Entry for 2 November 1809, IOR/G/12/168, 65 . 
defense of British interests in and around their new colony, necessitating a new set of responses from the Qing.

At the outbreak of the first Opium War, the Qing sent the lieutenant-colonel of the Dapeng 大鵬 battalion, Lai Enjue 賴恩爵, to Kowloon (Jiulong 九龍) to cut off supplies to British ships anchored in Victoria Harbour and restore peace to the surrounding seas. For his actions, he was promoted to fujiang 副將, or colonel (Xiao 1987, 55). Lai's post became particularly important after the signing of the Convention of Chuenpi (Chuanbi 穿鼻) in 1841, which secured the "cession of the island and harbor of Hongkong to the British Crown." ${ }^{13}$ The following year, British officials in Hong Kong began sending "certain Criminals" to the "Chinese Officer Commanding at Cowloon," across Victoria Harbour from Hong Kong Island. ${ }^{14}$ Given the acting governor of Hong Kong's report in October 1842 that "piracy has greatly increased in the Canton River and among the neighbouring Islands," it is likely that many of the criminals sent to Kowloon were pirates. ${ }^{15}$ This interaction set a precedent for Anglo-Qing cooperation against piracy.

Lai Enjue, however, would have lacked jurisdiction over pirates, crime being the responsibility of civil rather than military authorities (Antony 2016, 220-225). Recognizing this lacuna in Qing authority in Kowloon, Imperial Commissioner Qiying 耆英 decided “to send a Seunkeen [xunjian 巡檢], or inferior district officer, to reside at Kowlung [Kowloon], for the purpose of controlling the Chinese, and investigating the crimes they are accused of on the nearest spot."16 Emperor Daoguang 道光 (r.1820-1850) approved of Qiying's suggestion and ordered the personnel of the Guanfu 官富 deputy magistracy to "move their post to Kowloon, and change it to the Kowloon deputy magistracy, which will supplement deficiencies on the maritime frontier." He charged

13 Charles Elliot, "To Her Britannic Majesty's Subjects," 20 January 1841 in Chinese Repository, Vol. $X, 64$. The cession of Hong Kong to Britain was confirmed in the Treaty of Nanking (Nanjing 南京). See Article III of “Treaty of Nanking, 1842" (Imperial Maritime Customs [IMC] 1908, 160).

14 Woosnam to Caine, 24 April 1844, HKRS 100, 46.

15 Johnston to Aberdeen, 21 October 1842, CO 129/3, 148-149.

16 "Extract of a letter from the Imperial Commissioners to Sir Henry Pottinger," (date missing) February 1843, CO 129/3, 223. Translator unknown. "Seunkeen" is the Cantonese pronunciation of xunjian, or deputy magistrate. 
$\mathrm{Xu}$ Wenshen 許文深, the first deputy magistrate of Kowloon, with the task of "maintaining mutual peace between Chinese and barbarians."17

Guangdong Governor Cheng Yucai 程矞采 stated more explicitly that he had ordered "Dapeng colonel Shen Zhenbang 沈鎮邦 and Kowloon deputy magistrate $\mathrm{Xu}$ Wenshen ... to communicate through official correspondence or personal meetings" with British officials in Hong Kong. "When there are criminals, the bandits must be caught to set the people's hearts at ease. Officials cannot only limit their vigilance to the boundaries of their jurisdictions." ${ }^{18}$ The Kowloon deputy magistrate and colonel of Dapeng, known collectively in British sources as the Kowloon authorities, were specifically tasked with dealing with the problem of crime. As the representatives of Qing power closest to Hong Kong, they played an important role in mediating between and coordinating Qing and British efforts in suppressing piracy.

In response to a request from Hong Kong Governor Henry Pottinger for cooperation in suppressing piracy, Governor-General Qigong 祁熕 responded by sending Lai Enjue to Hong Kong. ${ }^{19}$ Lai provided his plans for intensifying actions against pirates in the "rivers and inner seas" while he would himself assemble a fleet to suppress pirates on the "outer seas." Interestingly, as a measure "to increase the efforts of capturing pirates on the seas, two interpreters would accompany any expedition going there to make inquiries." 20 Lai would have been well aware of the prowess of British ships in the "outer seas," having reported during the war that "sixteen English barbarian ships as well as one steamship" were operating there, and that "three-masted barbarian ships sail freely about the seas." ${ }^{21}$ Lai's decision to send interpreters with anti-piracy expeditions venturing to the outer seas suggests a willingness on his part to cooperate with the British and perhaps even rely on the Royal Navy to capture pirates and then hand them over to his forces.

Lai Enjue had the right to request the rendition of pirates through Article IX of the Supplementary Treaty of the Bogue (Humen 虎門), signed October 1843 . The article stipulated that "lawless Natives of China, having committed crimes, or Offences, against their own Government" who fled to "Hongkong or to the

17 Imperial Edict, Daoguang reign (DG) 23/10/xinyou (13 December 1843), Chou ban yi wu shi mo [Complete Records on Managing Barbarian Affairs, hereafter YWSM], Daoguang (DG) 70 juan $/ 18-19$.

18 Cheng Yucai to Pottinger, DG 24/3/18 (5 May 1844), FO 682/1977/56.

19 Governor-General Qigong to Pottinger, DG 23/2/13 (13 March 1843), FO 682/1976/55.

20 Lai Enjue to Pottinger, DG 23/1/24 (22 February 1843), FO 682/1976/49. On "inner" and "outer" sea space see Po 2016, 112-119.

21 Report by Regional Vice Commander at Dapeng Lai Enjue quoted in Memorial by Yishan, Qi Shen, Qigong, and Liang Baochang, DG 21/11/xinwei (2 January 1842), YWSM DG 40/26. 
English Ships of War or English Merchant Ships for refuge" were to be "handed over at once to the Chinese Officers for trial and punishment." ${ }^{22}$ Though the British and Qing had different understandings and interpretations of the treaty, the Kowloon authorities were eager to use this and any other means to suppress piracy and other crimes in the region. The British reciprocated this enthusiasm (Lee 2019, 89 and 99-100). In 1845, Qiying and Cheng Yucai memorialized that "the problem of piracy rages like wildfire across the seas around Guangdong to the point where there are cases of reckless acts of theft and murder." As a remedy, they suggested that Qing officials "must at all times search for and seize pirates and bandits and punish them so that law and discipline are enforced and relations between China and the outside world are peaceful."23 Qing officials saw the suppression of piracy as a matter of maintaining peaceful relations with the British and thus one of gravity.

The British proved willing to cooperate with the Qing in suppressing piracy. On 20 March 1845, the Kowloon authorities reported the presence of pirates in Aberdeen, on the southwest corner of Hong Kong Island, to the colonial magistrate. Assistant Harbor Master Alexander Lena proceeded there accompanied by two boats and a guide sent by the Kowloon authorities. The combined Anglo-Qing force captured eighteen pirates in one of the earliest recorded instances of cooperation between British and Qing forces against piracy. ${ }^{24}$ The following year, when acting chief magistrate Charles Hillier captured a pirate junk, he received orders to hand "the whole of the thirty seven persons ... to the Authorities at Kowloon, sending them in the captured Junk which may be towed over." 25 The British rendition of Chinese pirates to the Kowloon authorities developed into a modus vivendi for the suppression of piracy. The model of cooperation between the regimes on both sides of Victoria Harbour would be replicated between Royal Navy officers and local Qing authorities elsewhere along the coast of Guangdong.

Though Hong Kong and its surrounding waters were close to Canton, the provincial capital of Guangdong and a center of state authority, the Qing seem

22 Article IX of "Supplementary Treaty Signed by Their Excellencies Sir Henry Pottinger and Ki Ying Respectively, on the Part of the Sovereigns of Great Britain and China, at the Bogue, 8th October 1843" (IMC 1908, 201).

23 Memorial by Qiying and Cheng Yucai, DG 24/12/guisi (8 January 1845), YWSM DG 73/38.

24 China Mail, 27 March 1845; Ma 1936, 25.

25 William Caine to Charles Hillier, 26 June 1846, H KRS 100, 279. 
to have conceded British maritime jurisdiction over the colony's territorial waters. As early as 1841, Lai Enjue was already reporting that Hong Kong was in the "outer seas," implying that the island's surrounding waters were beyond Qing control. ${ }^{26}$ In a military report from the 1850 s, the provincial admiral of Guangdong recounts an expedition to "the barbarian seas of Black Water (Heishui 黑水) facing Hong Kong," likely a reference to Victoria Harbour. In the same report, he also describes Heishui as part of the "outer seas to the southwest." 27 In situating Hong Kong and Heishui in the outer seas, the Qing relinquished claims of control, while the labeling of Heishui as a "barbarian sea" seems an admission that it belonged to another power. Elsewhere along the coast and in Guangdong's rivers, however, British actions against pirates would have violated China's "inner sea" space, where the Qing claimed control (Po 2016, 112). ${ }^{28}$ Nonetheless, from British cooperation with the Kowloon authorities, the Qing recognized the prowess of British ships in suppressing piracy and often turned to them as instruments of maintaining order in Chinese islands and territory and even in waters beyond Qing jurisdiction.

\subsection{The Ladrones}

Long before the British colonized Hong Kong, Europeans called the group of islands that included Hong Kong the Ladrones, the Portuguese word for "thieves," so named for the prevalence of piracy in the region. While colonization may have introduced a strong state presence in Hong Kong, the British could do little about the other islands of the Ladrone group as they were under Chinese jurisdiction (Eitel 1895, 130-131). The Qing guarded their jurisdiction over the region of the Ladrones zealously. When Pottinger proposed constructing fortifications on Chaguoling 茶果嶺, on the other side of Victoria Harbour, Cheng Yucai responded that the

Treaty of Nanking clearly provides that only the island of Hong Kong has been ceded to England to administer. The limits of British jurisdiction and administration is the island. The area within the shores of the island is under the authority of Hong Kong. Areas beyond the shores of the island should be considered the territory of China.

26 Memorial by Yishan, Qi Shen, Qigong, and Liang Baochang, DG 21/11/xinwei (2 January 1842), YWSM DG 40/26.

27 Report by the Admiral of the Guangdong Provincial Water Force, undated (c. 1850s), FO 931/1047.

28 International law would have prevented the British from taking actions against Chinese pirates within three miles of the coast and in China's rivers. See Fox 1940, 89-91. 
Though Cheng did concede that "islets, harbors, and promontories" contiguous with Hong Kong were under British sovereignty, most of the seas and islands off the coast of Guangdong were under Qing jurisdiction. ${ }^{29}$

The island of Cheung Chau (Changzhou 長洲), which sat just outside Hong Kong's territorial waters, proved particularly problematic, as Chinese pirates could flee there and escape British jurisdiction. On 17 June 1844, 150 pirates attacked a warehouse in Victoria, on the northern side of Hong Kong Island, and fled to Cheung Chau when the Hong Kong police arrived. Governor John Davis requested that Qiying make "a rigid search ... on that island, to clear it, if possible of those public enemies." In support, Davis offered to "request His Excellency the Rear Admiral of Her Majesty's Squadron to cause one of his vessels to proceed thither." ${ }^{30}$ Qiying responded that since "Cheung Chau is not contiguous with Hong Kong, it is outside the extent of the island of Hong Kong and should be under Chinese administration." Qiying thus sent Lai Enjue to Cheung Chau to deal with the matter alone. ${ }^{31}$

Lai's actions proved inefficacious. A month after the attack at Victoria, two pirate ships from Cheung Chau attacked a ship carrying Colonel Farquharson and Captain D'Aguilar to Macao from Hong Kong. Davis, lamenting that this was "the third attack which we have suffered in less than three months," again urged Qiying to deal with the pirates. ${ }^{32}$ Being pressed yet again to take action against the pirates of Cheung Chau, Qiying ordered civil officials from the district of Xin'an 新安 as well as officials from the Dongguan 東莞 and Panyu 番禺 districts to coordinate with Lai Enjue in arresting the pirates. The mobilization of so many officials against pirates reflected the gravity Qiying ascribed to the problem, which he thought affected "mutual peace between Chinese and foreigners." ${ }^{33}$ British prodding thus pressured the Qing to coordinate civil and military officials from posts across the Pearl River Delta to take action against pirates on Cheung Chau. Such actions, however, seem to have been limited in effect, as the Qing continued to send expeditions to Cheung Chau into the 185 os. $^{34}$

By this time, however, the Qing, perhaps recognizing their inadequacies in suppressing piracy alone, began to accept assistance from foreigners. At the

\footnotetext{
29 Cheng Yucai to Pottinger, DG 24/3/18 (5 May 1844), FO 682/1977/55.

30 Davis to Qiying, 20 June 1844, CO 129/6, 287-288.

31 Qiying to Davis, DG 24/5/13 (28 June 1844), FO 682/1977/94.

32 Davis to Cochrane, 18 July 1844, ADM 125/145, 28.

33 Qiying to Davis, DG 24/6/9 (21 July 1844), FO 682/1977/112. Xin'an was the administrative district that held jurisdiction over the island of Hong Kong until 1841 (Carroll 2005, 18).

34 Report by the Commander-In-Chief of the Guangdong Provincial Water Force, undated (c. 1850), FO 931/1047.
} 
beginning of March $185^{\circ}$ "a Cowloon Mandarin" met with Captain J. W. Morgan, the senior naval officer in China, and requested assistance against pirates at “Kat O" (Ji'ao 吉澳, aka Crooked Island), an island off the northeast coast of Xin'an. ${ }^{35}$ Due to strong winds, Chinese war junks would struggle to proceed to Crooked Island quickly. Fearing the pirates might escape if quick action was not taken, the colonel of Dapeng dispatched a subordinate to request that the British send a steamship, offering to compensate them for the value of the coal used. ${ }^{36}$ Morgan sent Commander Lockyer of HMs Medea to "receive on board ... a Mandarin from the Cowloon side" and go after the pirates. ${ }^{37}$ The Medea returned the following day, her crew having reportedly killed more than 150 pirates and captured twenty. ${ }^{38}$ Two of the prisoners died, and the rest were delivered to the Kowloon authorities on 6 March $1850 .{ }^{39}$ Xu Guangjin 徐廣縉, the governor-general of Guangdong and Guangxi, approved of the expedition, stating to Bonham that "your honorable country's good intentions and amicability are sufficiently evident" and offered gifts to the crew of the Medea for their assistance. ${ }^{40}$

The acknowledged amicability of the British in assisting in suppressing piracy facilitated Qing willingness to cooperate with other states against pirates as well. In the $1850 \mathrm{os}$, a pirate known as "Awong" established a headquarters at Coulan (Gaolan 高欄) on another of the Ladrone islands beyond Hong Kong's jurisdiction. When pirates under Awong plundered the Chilean ship Caldera, which was commanded by a British subject, the British decided to take action. Rear-Admiral James Stirling, commander-in-chief of the East Indies and China Station, sought cooperation and intelligence from the Qing before seeking retribution, and in "consequence of a representation by the Governor of Hong Kong to the Governor General of Canton, the Heep cheem of Taipoong [i.e. the Dapeng colonel, Zhang Yutang 張玉堂] was ordered to accompany our men of war to destroy" Awong's fleet. ${ }^{41}$ Zhang Yutang was taken aboard HMS Barracouta, which was accompanied by HMS Encounter and HMS Styx as well as the American-chartered steamer Queen, and the Portuguese lorcha Amasona sent by the governor of Macao. The anti-piracy expedition, which included British, Portuguese, Qing, and American subjects, destroyed fifty-one

\footnotetext{
35 Morgan to Plumridge, 4 March 1850, ADM 125/145, 114.

36 Bonham to Xu Guangjin, 8 March 185o, FO 677/26, 45.

37 Morgan to Lockyer, 4 March 1850, ADM 125/145, 116.

38 Lockyer to Morgan, 5 March 1850, ADM 125/145, 118-120.

39 China Mail, 7 March 1850.

$40 \quad \mathrm{Xu}$ to Bonham, DG 30/3/1 (14 March 1850), FO 677/26, 45.

41 D. R. Caldwell, "An Account of the Principal Piratical Fleets and their Chiefs since the year 1849," 2 May 1859, ADM 125/4, 393-395.
} 
pirate junks and captured ten Chinese pirates in November 1854 (Sellick 2010, 131-136). The force also razed three villages deemed piratical and destroyed several shore batteries (Wombwell 2010, 112-113). Governor-General Ye Mingchen 葉名琛 approved of the expedition, declaring it "sufficient evidence of sincere intentions against a common enemy." 42 By the mid-nineteenth century, the problem of piracy and its threat to Qing control had become so grave that Qing officials began to allow foreign warships to take actions against pirates not only in Chinese waters but also on land.

\subsection{Chinese Territory and Territorial Waters}

From 28 September to 1 October 1849, HMS Columbine, commanded by Captain John C. Dalrymple Hay, and supported by the Peninsular and Oriental Company's steamer Canton and later by H Ms Fury, engaged and defeated the fleet of Chui Apo (Xu Yabao 徐亞保) in Bias Bay “40 NMiles to the eastward" of Hong Kong, well beyond that island's territorial waters. ${ }^{43}$ By 29 September, the British had killed more than $25^{\circ}$ pirates. ${ }^{44}$ Two days later, the Fury, taking on a Chinese fisherman as a pilot, sailed up a river and continued attacking pirates. Edward Cree, a surgeon aboard the Fury, recorded that in total twenty-seven pirate vessels were destroyed with 400 pirates killed. A group of Royal Marines landed to pursue "the rest, upwards of a thousand, [who] escaped to shore." In the process, the British destroyed "a large village and a dockyard with quantities of arms and ammunition and three new junks building." 45 The expedition against Chui Apo marks an early instance of the British exercise of what Simon Layton terms the "imperialism of free seas" in China (Layton 2013, 224 and 2011, 83 and 88-89). The British used the suppression of piracy to justify intervention in Qing maritime and territorial space in the interest of protecting trade and free navigation.

Chui Apo, who was charged with murdering two British soldiers in Hong Kong, escaped the engagement with the British alive. ${ }^{46}$ Governor George Bonham thus requested his capture and rendition to Hong Kong. Xu Guangjin responded:

In this case, the murderer Chui Apo is a person of China. If he is captured by British officials, according to the treaty, he ought to be handed over to

\footnotetext{
42 Ye to Bowring, XF 4/10/18 (7 December 1854), FO 230/75, 61.

43 Entry for 30 September $1849, \mathrm{CRJ} / 12,55$.

44 Commander John C. Dalrymple Hay to Rear-Admiral Collier, 30 September 1849 in Hong Kong Register, 18 October 1849, CRJ/31-35.

45 Entry for 1 October 1849, CRJ/12, 59.

46 On the murders see "Coroners Inquest," 1 March 1849, CO 129/28, 365-367.
} 
officers of China for trial. How can it be that if he were captured on the mainland, he should be on the contrary handed over for foreign trial? Because he has committed a case of theft with murder, if he is found and captured, I resolutely refuse to treat him with levity.

In the same letter, Xu cited a precedent: "when many suspected of piracy were captured at Jinxingmen 金星門, the prisoners were forwarded to the Kowloon office and transferred to the Dapeng garrison commander who forwarded them to Canton. This is permitted." ${ }^{27}$ While Xu approved of the British practice of rendering Chinese pirates to the Kowloon authorities, he saw such pirates as Qing subjects and denied the British jurisdiction over them.

Furthermore, Xu saw the British victory against Chui Apo's fleet as a result of Qing efforts in suppressing piracy. Prior to the engagement at Bias Bay, he noted to Bonham that the magistrate of Guishan 歸山 district and the commander of the Pinghai 平海 garrison opened fire from the Chehui 車繪 battery and "sank three pirate boats and burned another. More than one hundred pirates were killed." The action drove the pirates to Shanwei 汕尾, “where the Shanwei soldiers and militia attacked them and drove them to the outer seas, where they met with your honorable country's cruisers." On receiving news of the Royal Navy's defeat of Chui's fleet, Xu "immediately issued orders to the coastal districts and garrisons to make searches and seizures, hoping that the remaining pirates would be completely cleared from the area," further promising that if Chui Apo was captured, "he would certainly be dealt with and punished severely." 48

The defeat of Chui Apo's fleet resulted from indirect cooperation between Qing forces on land and the Royal Navy at sea. Xu Guangjin seems to have turned a blind eye to British violations of Qing maritime and territorial sovereignty. Instead, his orders to coastal authorities to increase efforts at seizing pirates in the wake of Captain Hay's expedition show he was willing to capitalize on a Royal Navy victory to further effect the suppression of piracy. On the matter of jurisdiction over Chui Apo, Xu Guangjin eventually proved amenable to British demands. Governor Bonham cited the need to capture Chui as a potential justification for further expeditions against pirates and warned that if "accidents should happen through ignorance on our part, the blame must attach to the Chinese Viceroy for not having early caused the miscreant to be apprehended." ${ }^{49}$ Perhaps concerned about continued British intervention in

47 Xu Guangjin to Bonham, DG 29/8/20 (6 October 1849), FO 682/1982/44.

48 Xu Guangjin to Bonham, DG 29/8/25 (11 October 1849), FO 682/1982/45.

49 Quoted in China Mail, Overland Edition, 1 November 1849, in Scott 1851, 100. 
Chinese waters, Xu eventually acceded that "Chui Apo is a criminal because he has murdered and violated the law. Such is this atrocity that it must be punished regardless of boundaries." He qualified the cession of jurisdiction over Chui Apo to the British by admitting that "Hong Kong residents and those living there temporarily are all under British jurisdiction and administration. China has not the slightest right to interfere or claim simultaneous jurisdiction." 50

Xu's acceding to British jurisdiction over Chui Apo further affirmed British sovereignty over Hong Kong. More importantly, his relinquishing of jurisdiction over a Chinese pirate marked the beginning of the Qing recognition of the doctrine of universal competence in the European law of nations. While Xu's statement lacked any reference to international law, as such vocabulary was as yet unavailable, the claim that Chui's "atrocity" warranted his trial by the British suggests an acceptance, to some degree, that Chinese piracy could be within foreign jurisdiction (Svarverud 2011, 311). Qing authorities captured Chui Apo the following year in Canton. ${ }^{51}$ True to his acceptance of British jurisdiction over Chinese pirates, $\mathrm{Xu}$ had Chui sent to Hong Kong for trial; Chui was convicted of manslaughter but committed suicide in prison before his sentence of transportation for life could be carried out (Norton-Kyshe 1898, 297-298). The concession of jurisdiction over a pirate like Chui Apo, engaged in Chinese territorial waters and captured in China, helped catalyze further cooperation against pirates both in Chinese territorial waters, as in the expedition against Awong at Coulan, as well as in areas beyond Qing and British maritime jurisdiction.

\subsection{Barbarian Seas}

The increased amicability between the British and Qing after the successful defeat of Chui Apo's fleet paved the way for one of the most successful Anglo-Qing joint ventures against piracy in history. The disruption caused by another pirate, Shap-ng-tsai (Shi Wu Zai 十五仔), warranted another exercise in the imperialism of free seas. Rear-Admiral Francis Collier gave Captain John C. Dalrymple Hay, who had recently defeated Chui Apo, command of H Ms Columbine, HMS Fury, and HCs Phlegethon as well as a "carte blanche" to go after Shap-ng-tsai (Hay 1898, 178). On 13 October 1849, Hay's flotilla anchored off Haikou 海口 on Hainan 海南 Island. Hay met with the "governor," who "offered to render any assistance in destroying the pirates" and accordingly dispatched "naval commander, Wang-Hai-Quang (Huang Kaiguang 黃開廣),

50 Xu Guangjin to Bonham, DG 29/9/2 (17 October 1849), FO 677/26, 75.

51 China Mail, 1 August 1850. 
an acting major-general in the Chinese service" to accompany the expedition. ${ }^{52}$ Huang Kaiguang boarded the Fury along with several underlings and led a fleet of eight war junks to accompany the expedition.

The combined Anglo-Chinese fleet engaged Shap-ng-tsai's fleet at "Chokeum" in Cochin China (Vietnam), called the "barbarian sea of Huafeng 花封” or the "Annamese [Vietnamese] sea of Huafeng" in Chinese accounts. In his report, Hay claimed an astounding victory in which " 58 piratical vessels mounting about 1200 guns and with crews of 3000 men" were defeated "without the loss of one life of the officers and men under my orders." ${ }^{3}$ In reporting to Huang Kaiguang's superior, “His Excellency, The Illustrious 'Ho', Governor General of Hainan and Eleven Provinces," Hay stated that "1700 of the pirate ships' crews have been slain by us, and that about 300 only out of 3000 escaped in the six small vessels with Shap-ng-tzai ... and that a few Guns and prisoners as trophies have been brought over and are at Your Excellency's disposal." ${ }^{54}$ The Times reported that the Royal Navy had handed over 180 pirates to the Chinese. ${ }^{55}$ Normally, Qing officials would have respected Vietnam's maritime space. Qing naval forces rarely pursued pirates past the Bailongwei Peninsula marking the Sino-Vietnamese border (Murray 1999, 157). Qing officials only transgressed the maritime boundary when cooperating with Vietnamese counterparts (Nguyen 2019, 78-79; Chen 2011, 3). By taking Huang Kaiguang on board H Ms Fury and handing prisoners from Shap-ng-tsai's pirate gang over to him, the Royal Navy took the place of Vietnamese officials and extended Qing jurisdiction into foreign waters.

After receiving Captain Hay's report of the defeat of Shap-ng-tsai's fleet, He Fang 何芳 (the "Illustrious Ho") reported to Bonham that he had previously "issued a war proclamation to Huang, commander of the garrison guarding Haikou, and other commanders to take a squadron of warships and to supplement their forces by recruiting merchantmen and provisioning them with arms." He further ordered civil officials to raise militia forces. Rather than seeing the British as taking an initiative against pirates, He claimed that Hay's flotilla "sailed to Haikou and sought to proceed in company with the imperial forces to capture pirates." After the expedition, on "the barbarian sea of a place called Huafeng, all the pirates were handed over to local authorities for

\footnotetext{
$5^{2}$ Entry for 13 October $1849, \mathrm{CRJ} / 12,64-65$.

53 Hay to Collier, 23 October 1849, ADM 125/145, 98-99; He Fang to Bonham, DG 29/9/11 (26 October 1849), FO 682/1982/50; Memorial by Xu Guangjin, DG 29/11/15 (28 December 1849), FO 931/1034.

54 Hay to Ho, 25 October 1849, ADM 125/145, 102-103. In reality, the official in question, He Fang, was the colonel of Yaizhou. See FO 931/1034.

Times, 22 January $185^{\circ}$ in Scott 1851, 172.
} 
investigation. Afterwards, many pirates were forwarded to provincial authorities for interrogation." He Fang concluded that "we are still at the same time making an earnest search for the pirate chieftain Zhang Shi Wu Zai; when that is accomplished and the outside is harmonious, I will report this." ${ }^{56}$

Despite the victory against Shap-ng-tsai, Xu Guangjin dismissed He in late 1849 for failure in suppressing piracy. In the same memorial, Xu noted local officials' capture of ninety-six pirates, citing the arrests as deterring the pirates from "continuing their activities in the inner ocean." Forced into the outer seas, the pirates met with the British, who "pursued the pirates to the sea of Huafeng in Annam ... Annam also detested that the pirates had crossed into their borders causing disturbances and joined in attacking the pirates." Xu commented that this joint effort "was a severe blow to the pirates, and they will be unable to restore their former strength. Now that the pirates have been defeated by outer barbarians, it will be difficult to ensure they will not reassemble their remnants and scurry back to the inner seas." Despite the report that "the number of pirates killed or drowned was in the hundreds," the Qing remained wary of the British. ${ }^{57}$ Having credited themselves with driving the pirates beyond China's coastal waters, Qing officials now blamed British activity in the outer seas for driving pirates back to China.

Although they continued to mistrust the British, the successes against Shap-ng-tsai and other pirates helped Qing officials realize the usefulness in cooperating with the British against piracy. Thus, while noting that "barbarian foam has not yet settled," Xu Guangjin nonetheless admitted that

the contemporary situation in Guangdong is very different from the past. In the past, we only needed to deal with mainland bandits. Now we must also simultaneously deal with outer barbarians. If the outer barbarians and mainland marauders become enemies, the outer barbarians can cut off the escape of mainland marauders. ${ }^{58}$

The Qing, having seen the might of the Royal Navy during the First Opium War and then in subsequent actions against Chinese pirates, came to realize the British could be efficacious, if dubious, allies against pirates. The British increased their actions against pirates after the colonization of Hong Kong. While this impinged on Qing sovereignty, local and even provincial officials

$56 \quad$ FO $682 / 1982 / 50$.

$57 \quad$ FO 931/1034.

$5^{8}$ Memorial by Xu Guangjin, DG 30/4/22 (2 June 1850), FO 931/1202. The Chinese used the term "bandit" to describe a variety of crimes, including piracy (Antony 2016, 105-107). 
in Guangdong took advantage of British naval superiority and used the Royal Navy to suppress piracy. Murakami Ei, referencing the Qing practice of zhaofu 招撫, in which Qing officials commissioned former pirates against other pirates, considers Qing reliance on British assistance akin to a zhaofu of the Royal Navy (Murakami 2013, 238). Through cooperation, the modus vivendi for suppressing Chinese piracy that developed between the British in Hong Kong and the Kowloon authorities across Victoria Harbour could be extended along the China coast and even to waters beyond Qing maritime jurisdiction.

Despite its versatility and efficaciousness, the system of cooperation developed between the Qing and British before 1860 was haphazard and informal. It would take another war and another treaty to formalize Anglo-Qing cooperation in suppressing piracy (Preston and Major 2007, 52). Matters of jurisdiction over Chinese pirates remained unclear. When a member of the Cantonese gentry claimed to recognize a pirate among the crew of the Hong Kong-registered lorcha Arrow, Qing authorities proceeded, on 8 October 1856, to arrest the crew in waters near Canton. In the process, the Qing officials allegedly hauled down the British flag, under which colonial vessels registered in Hong Kong acquired a right to sail in May 1856. British agents construed this routine arrest of pirates into a national insult, which then justified the Arrow War (1856-1860), also known as the Second Opium War (Wong 1998, 44 and 62-63). ${ }^{59}$ Regardless of whether the Arrow was flying the British flag, Qing officials had been receiving pirates from the British for over a decade and may not have seen the arrest of pirates aboard the Arrow as a violation of British sovereignty. ${ }^{60}$ While the British merely used the Arrow incident as a pretext for furthering their aims in China, Ye Mingchen continued to justify his exertion of jurisdiction over Chinese pirates even after hostilities commenced (Wong 1998, 98).61

The Arrow War resulted in the Treaty of Tientsin (Tianjin 天津, 1858), ratified by the Convention of Peking (Beijing 北京, 1860), which made it "the duty of the

59 John Wong claims the Arrow incident simply provided a pretext for hostility, which the British government had planned for some time beforehand (Wong 1998, 29).

6o The rights of the crew of the Arrow to British protection is dubious as the ship's register expired 27 September 1856 (Wong 1998, 71).

61 As late as December 1857, several weeks before his capture by the British, Ye Mingchen still insisted that he had jurisdiction over the Chinese pirates on board the Arrow. See Ye to Lord Elgin, Xiangfeng (XF) reign, 7/11/10 (14 December 1857), FO 230/75, 98. 
Chinese authorities to use every endeavour to capture and punish ... robbers or pirates." ${ }^{2}$ The treaty also stipulated that due to "the prevalence of piracy, in the seas of China, the High Contracting Parties agree to concert measures for its suppression." ${ }^{63}$ In endeavoring to suppress piracy the Qing could consider cooperation with, and indeed reliance on, the Royal Navy. The Treaty of Tientsin merely gave the modus vivendi that developed between the British and Qing authorities for the suppression of piracy a legal basis in treaty law. Cooperation, however, was only one of the adaptations of the Qing to the British suppression of piracy before the Arrow War. British pressure galvanized more intense and coordinated Chinese action against piracy, often involving civil and military officials from multiple jurisdictions. British actions against pirates in the outer seas also emboldened Qing naval actions. A year after the defeat of Shap-ng-tsai, Qiongzhou 瓊洲 regional commander Huang Qingyuan 黄慶元, Lei-Qiong 雷瓊 region circuit intendant Jiang Guolin 江國 霖, and Qiongzhou prefect Lin Hongnian 林鴻年 coordinated with local gentry to raise a force to attack pirates in "the barbarian seas of Goutoushan 狗頭山." ${ }^{4}$

While this expedition into barbarian seas was executed by traditional naval forces and did not mark the Qing embrace of navalism, it shows that the Qing were beginning to shift their scope of naval action to the outer and barbarian seas (Swanson 1982, 54-55; Murray 2004, 43). In most cases, however, the Qing still relied on the British for suppressing piracy in the outer seas and beyond. As the British usually handed over captured pirates to Qing authorities, the latter could in effect use the Royal Navy to extend Qing jurisdiction. The willingness of Qing officials to accompany or provide guides for British expeditions against pirates suggests an awareness that British ships could be vectors of Qing law beyond the scope of Qing naval action. ${ }^{65}$ British suppression of piracy also became an arena in which the Qing engaged with the European law of nations, as evidenced in the debates over the extradition of Chui Apo to Hong Kong or the cause of the tragic Arrow War. Qing reactions to the British suppression of piracy in southern China before 1856 thus represented not only an accommodation of an imperial power, but also a co-opting of Royal Navy forces to uphold Qing order in the China seas as well as a means of engaging with the ascendant international law.

\footnotetext{
62 Article XIX of the Treaty of Tientsin (1858) (IMC 1908, 218).

63 Article LIII of the Treaty of Tientsin (1858) (IMC 1908, 227).

64 Memorial by Xu Guangjin, XF 1/1/22 (22 February 1851), FO 931/1273. Cree records the location of "Go-To-Shan" as "on the Tonquin Coast." See Entry for 16 October, CRJ/12, 69.

65 Lauren Benton describes ships as "vectors of law thrusting into ocean space" (Benton 2010, 112).
} 


\section{References}

\section{Archives}

Admiralty: China Station Correspondence, ADM 125, The National Archives (TNA), London.

Colonial Office: Hong Kong, Original Correspondence, CO 129, TNA, London.

Correspondence received by the Chief Police Magistrate from the Colonial Secretary, 2 February 1844-31 December 1846, HKRS 100, Public Record Office, Hong Kong.

Foreign Office: Chinese Secretary's Office, Various Embassies and Consulates, China: General Correspondence, FO 682, TNA, London.

Foreign Office: Consulates and Legation, China: Letter Books, FO 230, TNA, London. Foreign Office: The Guangdong Provincial Archives, FO 931, TNA, London.

India Office Records: Factory Records: China and Japan, IOR/G/12, British Library, London.

Northern Department and Foreign Office: Consulates and Legation, China: Miscellaneous Papers and Reports, FO 233, TNA, London.

The Private Illustrated Journals of Dr. E. H. Cree, CRJ, Caird Library, National Maritime Museum, London.

\section{Published Primary Sources}

\section{China Mail}

\section{Chinese Repository}

Imperial Maritime Customs, Treaties, Conventions, Etc. Between China and Foreign States, Vol. I. Shanghai: Statistical Department of the Inspectorate General of Customs, 1908.

Scott, Beresford, ed. 1851. An Account of the Destruction of the Fleets of the Celebrated Pirate Chieftains Chui-apoo and Shap-ng-tsai, on the Coast of China, in September and October, 1849, By Her Majesty's Sloop “Columbine," Commander John C. Dalrymple Hay; Steam Sloop "Fury," Commander J. Willcox; and Hon. E. I. Co.'s Armed Steam Vessel "Phlegethon," G. J. Neblett, Esq. Commander: Collected principally from the Press, Colonial and British, as published at the time. London: Savill and Edwards.

Wenqing 文慶, Jia Zhen 賈楨, Baoyun 寶菳, ed. Qingdai chouban yiwu shimo 清代籌 辦夷務始末 [A Comprehensive Account of the Management of Barbarian Affairs During the Qing Dynasty]. Shanghai: Shanghai guji chubanshe, 1995.

\section{Published}

Antony, Robert J. 2003. Like Froth Floating on the Sea: The World of Pirates and Seafarers in Late Imperial South China. Berkeley, CA: Institute of East Asian Studies.

Antony, Robert J. 2016. Unruly People: Crime, Community, and State in Late Imperial South China. Hong Kong: Hong Kong University Press. 
Benton, Lauren. 2010. A Search for Sovereignty: Law and Geography in European Empires, 1400-1900. Cambridge: Cambridge University Press.

Benton, Lauren. 2011. "Toward a New Legal History of Piracy: Maritime Legalities and the Myth of Universal Jurisdiction." Journal of International Maritime History 12, no. 1 (June): $225^{-240 .}$

Carroll, John M. 2005. Edge of Empires: Chinese Elites and British Colonials in Hong Kong. Cambridge, MA: Harvard University Press.

Chappell, Jonathan. 2018. "Maritime Raiding, International Law and the Suppression of Piracy on the South China Coast, 1842-1869." The International History Review 40, no. 3: 473-492.

Chen, Li. 2016. Chinese Law in Imperial Eyes: Sovereignty, Justice, and Transcultural Politics. New York: Columbia University Press.

Chen, Yu-xiang 陳鈺祥. 2011. "Qingchao yu Yuenan bianjing de haidao qingxing 清朝 與越南邊境的海盜情形 [The Problem of Piracy at the Sino-Vietnamese Border].” In Hanghai: wenming zhi ji 航海: 文明之跡 [Navigation: Traces of Civilization], edited by the China Maritime Museum, 1-9. Shanghai: Shanghai guji chubanshe.

Eitel, E. J. 1895. Europe in China: From the Beginning to the Year 1882. Hong Kong: Kelly and Walsh.

Fox, Grace Estelle. 1940. British Admirals and Chinese Pirates, 1832-1869. London: K. Paul, Trench, and Trubner.

Graham, Gerald S. 1978. The China Station: War and Diplomacy, 1830-1860. Oxford: Clarendon Press.

Hay, J. C. D. 1898. Lines from my Log-Book. Edinburgh: David Douglas.

Layton, Simon. 2013. "Hydras and Leviathans in the Indian Ocean World." International Journal of Maritime History 25, no. 2 (December): 213-225.

Layton, Simon. 2011. "Discourses of Piracy in an Age of Revolution." Itinerario 35, no. 2 (August): 81-97.

Lee, Ivan. 2019. "British Extradition Practice in Early Colonial Hong Kong." law\&history 6, no. 1: $85^{-114}$.

Ma, Yuan 馬沅 [Ma Yuen]. 1936. Xianggang fa li hui bian, yice: Fazhi shishi 香港法例 彙編, 乙冊：法制史實 [Ordinances of Hong Kong 1844-1936 Translated into Chinese, Vol. II: A History of Hong Kong's Legal Institutions]. Hong Kong: Overseas Chinese Daily News.

Morse, Hosea Ballou. 1926. The Chronicles of the East India Company Trading to China, Vols. I-V. Oxford: Oxford University Press.

Morse, Hosea Ballou. 1910. The International Relations of the Chinese Empire, Vol. I: The Period of Conflict, 1834-1860. London: Longmans, Green, and Co.

Murakami, Ei 村上衛. 2013. Haiyang shishang de jindai Zhongguo: Fujian ren de huodong yu Yingguo Qing chao de yinying 海洋史上的近代中國: 福建人的活動 與 英國、清朝的因應 [A Modern Maritime History of China: Fujianese Activity 
and British and Qing Responses]. Translated by Shilun Wang 王詩倫. Beijing: Social Sciences Academic Press, 2013.

Murray, Dian. 1999. “Guangdong de shuishang shijie: ta de shengtai he jingji 廣東的 水上世界：牠的生 態和經濟 [The Cantonese Water World: Its Ecology and Economy]" trans. Zhang Bincun 張涁村. In Zhonguo hai yang fa shan shi lun wen $j i$ 中國海洋發展史論文集 [Collected Essays on the History of Chinese Maritime Development] 7, no. 1, edited by Xiyong Tang 湯熙勇, 145-170. Taipei: Academia Sinica, 1999 .

Murray, Dian. 2004. "Piracy and China's Maritime Transition, 1750-1850." In Maritime China in Transition 1750-1850, edited by Gungwu Wang and Chin-Keong Ng, 43-6o. Wiesbaden: Harrassowitz Verlag.

Murray, Dian. 1987. Pirates of the South China Coast, 1790-1810. Stanford: Stanford University Press.

Nguyen, Thi My Hanh. 2019. "The Anti-Piracy Activities of the Nguyen Dynasty in the South China Sea, 1802-1858." International Journal of Maritime History 31, no. 1: 50-80.

Norton-Kyshe, James William. 1898. The History of the Laws and Courts of Hong Kong: Tracing Consular Jurisdiction in China and Japan and Including Parliamentary Debates, and the Rise, Progress, and Successive Changes in the Various Public Institutions of the Colony from the Earliest Period to the Present Time, Vol. 1. London: T. Fisher Unwin.

Po, Ronald C. 2016. "Mapping Maritime Power and Control: A Study of the Late Eighteenth Century Qisheng Yanhai Tu (A Coastal Map of the Seven Provinces)." Late Imperial China 37, no. 2 (December): 93-136.

Preston, Anthony, and John Major. 2007. Send a Gunboat: The Victorian Navy and Supremacy at Sea, 1854-1904, revised edition. London: Conway.

Rubin, Alfred P. 1988. The Law of Piracy. Newport, RI: Naval War College Press.

Sellick, Douglas, ed. 2010. Pirate Outrages: True Stories of Terror on the China Seas. Fremantle, AU: Fremantle Press.

Svarverud, Rune. 2011. "Re-Constructing East Asia: International Law as Inter-Cultural Process in Late Qing China." Inter-Asia Cultural Studies 12, no. 2: 306-318.

Swanson, Bruce. 1982. Eighth Voyage of the Dragon: A History of China's Quest for Seapower. Annapolis: Naval Institute Press.

Van Dyke, Paul. 2007. The Canton Trade: Life and Enterprise on the China Coast, 17001845. Hong Kong: Hong Kong University Press.

Wakeman, Jr, Frederic. 2004. "Drury's Occupation of Macao and China's Response to Early Modern Imperialism." East Asian History 28: 27-34.

Wombwell, James A. 2010. The Long War Against Piracy: Historical Trends. Fort Leavenworth, KA: Combat Studies Institute Press.

Wong, John Y. 1998. Deadly Dreams: Opium, Imperialism, and the Arrow War (1856-1860) in China. Cambridge: Cambridge University Press.

Xiao, Guojian 蕭國健 [Anthony Siu]. 1987.Jiulong cheng zhai shi lunji 九龍城寨史論 集 [Studies on the Kowloon Walled City]. Hong Kong: Hin Chiu Institute. 